\title{
Photoadaptation and diel periodicity of photosynthesis in the dinoflagellate Prorocentrum mariae-lebouriae
}

\author{
L. W. Harding, Jr. ${ }^{1}$, B. W. Meeson ${ }^{2}$ and M. A. Tyler ${ }^{3,1}$ \\ ${ }^{1}$ Chesapeake Bay Institute, The Johns Hopkins University, Shady Side, Maryland 20764, USA \\ ${ }^{2}$ Chesapeake Bay Center for Environmental Studies, Smithsonian Institution, P. O. Box 28, Edgewater, Maryland 21037, USA \\ ${ }^{3}$ College of Marine Studies, University of Delaware, 700 Pilottown Road, Lewes, Delaware 19958, USA
}

\begin{abstract}
Prorocentrum mariae-lebouriae, a dinoflagellate which commonly forms red tides in Chesapeake Bay (USA), is shown to exhibit diel periodicity of photosynthesis and pronounced photoadaptive responses to changes in its photic environment. These 2 physiological characteristics are both manifested as shifts in the photosynthesis-irradiance (P-I) relationship. A new culture methodology is used to separate changes in the P-I curve parameters ( $\alpha$ and $P_{\max }$ ) that are associated with rhythmicity of photosynthesis from those accompanying light adaptation. This culture approach provides populations of cells that are individually phased to distinct light-dark schedules, allowing periodicity and light adaptation to be studied concurrently. P. mariae-lebouriae shows diel periodicity of photosynthesis comparable to the time-dependent patterns detected for many other phytoplankton species. The amplitude of diel oscillations in P-I curves ranged from 1.4 to 2.5 , depending on the photic regime. Maxima in $\alpha$ and $\mathrm{P}_{\max }$ occurred in mid-morning on a high light cycle, but shifted to midday following a reduction in light availability. This species also adapts rapidly to changes in irradiance. Chlorophyll (chl) a increased from 2.6 to $5.1 \mathrm{pg} \mathrm{cell}^{-1}, \mathrm{chl} \mathrm{c}$ from 1.8 to $3.0 \mathrm{pg} \mathrm{cell}^{-1}$, and peridinin from 2.2 to $3.1 \mathrm{pg} \mathrm{cell^{-1 }}$ within $72 \mathrm{~h}$ of a shift to low light. An accompanying increase in the ability to harvest light, exhibited as an increase in $\alpha$ cell $^{-1}$, enabled the cells to fix carbon at the same rate in low light as occurred in high light. During this $72 \mathrm{~h}$ interval, however, cells did not maintain a maximal division rate as $\mu_{\text {cell }} \rightarrow 0$. A combination of strategies to cope with perturbations in the photic regime involving changes in photosynthesis, pigmentation, and cellular carbon is documented and discussed in the context of temporal specificity of individual photoadaptive responses.
\end{abstract}

\section{INTRODUCTION}

Photoadaptation in marine phytoplankton has been studied extensively because these microalgal cells frequently experience changes of their light environment in nature. Phytoplankton cells must possess sufficient physiological plasticity to grow in a dynamic photic regime where movement in the water column by physical processes and motility, changes in sunlight intensity and photoperiod, and differences in clarity due to turbidity and the biomass of phytoplankton can change the amount of light available to drive photosynthetic carbon assimilation and growth (reviews: Falkowski, 1980; Prézelin, 1981; in press). In the past $6 \mathrm{y}$, research on the physiological ecology of phytoplankton has focused on the adaptive mechanisms cells use to cope with variations in the light field (cf. Beardall and Morris, 1976; Prézelin and Sweeney, 1978; Falkowski,
1980; Perry et al., 1981; Rivkin et al., 1982a; Prézelin, in press). Most of these studies on photoadaptive strategies have concentrated on cellular responses to changes in light availability wherein phytoplankton alter their biochemical composition and photosynthetic properties when confronted with a shift in light intensity (Steeman Nielsen and Park, 1964; Yentsch and Lee, 1966; Hellebust and Terborgh, 1967; Brown and Richardson, 1968; Mandelli, 1972; Beardall and Morris, 1976; Prézelin, 1976; Boardman, 1977; Fleischhacker and Senger, 1978; Prézelin and Alberte, 1978; Prézelin and Sweeney, 1978, 1979; Senger and Fleischhacker, 1978; Falkowski and Owens, 1980; Marra, 1980; Prézelin and Matlick, 1980; Perry et al., 1981). Such experimental light-shifts and the responses they evoke in phytoplankton cells have been used to predict how cells respond in nature to analagous shifts in their photic environment. 
Two principal strategies for adaptation to low light involve changes in photosynthetic pigments resulting from photo-induced synthesis of particular components of the photosynthetic apparatus. These strategies have been colloquially termed 'size' and 'number' adaptation (cf. Prézelin and Sweeney, 1979; Falkowski and Owens, 1980), and correspond to an enhanced synthesis of: (1) light harvesting components (LHC) relative to reaction center $(\mathrm{RC})$ chlorophyll molecules in photosynthetic units, or PSU's (= 'size' change); (2) LHC and $\mathrm{RC}$ in equimolar proportions, presumably indicating an increase in PSU's per cell (= 'number' change). Details of these strategies have been presented in several extensive reviews (e. g. Falkowski, 1980; Prézelin, 1981; in press.)

The 'adaptive' characteristic of a photoadaptive or light-shade strategy has been postulated to be a maintenance of growth rate $\left(\mu_{\text {ceill }}\right)$ in low light, accrued by increased rates of photosynthetic carbon assimilation per cell at low light levels as compared to rates in 'unadapted' cells (Prézelin and Sweeney, 1978; Falkowski, 1980; Prézelin and Matlick, 1980). This enchancement of carbon assimilation associated with a photoadaptive response has usually, but not always (Rivkin et al., 1982a), been attributed to the increase in pigments described above. The result is that a cell undergoing light-shade adaptation may continue growing at low light levels by increasing its per cell carbon fixation. Carbon fixation per unit chlorophyll a usually declines when cells adapt to low light as a result of the increase in pigment levels per cell.

Research supporting the concepts presented above has provided some important insights into strategies of photoadaptation. In most studies of photoadaptation, however, phytoplankton have been grown in lightdark schedules where illumination does not vary in intensity during the light period. This simple means of providing light has worked well in terms of defining some potential strategies (cf. Prézelin and Sweeney, 1979; Falkowski and Owens, 1980, Perry et al., 1981), but in nature cells are exposed to variations in irradiance. If cells undertake different physiological adjustments when grown in light conditions that mimic variations in sunlight intensity during the day, and are not simply cued by the total amount of light (as discussed by Marra and Heinemann, 1982), results obtained using a constant light environment could prove misleading.

In addition, parameters of the photosynthesisirradiance (P-I) relationship that are often used to diagnose photoadaptive responses undergo diel oscillations. This periodicity can mask P-I curve changes which are actually associated with a shift in light availability. For example, several of the species whose photoadaptive strategies have been studied exten- sively also show periodicity of photosynthesis (e. g. Lauderia borealis, Gonyaulax polyedra, Glenodinium sp. - Prézelin and Sweeney, 1977; Marra, 1978; Prézelin and Matlick, 1980; Harding et al., 1981a). In these cases, exemplified by the often-studied dinoflagellate Gonyaulax polyedra, periodicity and photoadaptation are both manifested as changes in $\alpha$ and $P_{\max }$, the slope and asymptote of the P-I relationship (Prézelin and Sweeney, 1977, 1978). Studies which describe directional changes in $\alpha$ and $P_{\max }$ that accompany a lightshift should also consider diel oscillations of these parameters because rhythmic and photoadaptive changes can be of comparable magnitudes

We have used a new culture device to provide variations in light intensity and to separate changes in $\alpha$ and $P_{\max }$ that are associated with diel periodicity of photosynthesis from those accompanying reduced light availability. This technique employs the 'wheel' (described in detail in 'Materials and Methods') which was originally developed for studies of bioluminescence rhythms in Gonyaulax polyedra in Dr. Beatrice M. Sweeney's laboratory by her graduate student, Douglas Foster. A modification of this culture device was used to provide a varying light regime, and to phase individual cultures to distinct light-dark schedules.

Photoadaptation and diel periodicity of photosynthesis in the dinoflagellate Prorocentrum mariaelebouriae were studied concurrently using the 'wheel'. $P$. mariae-lebouriae is a common member of the phytoplanktonic flora in the Chesapeake Bay; it undergoes a lengthy seasonal transport in low-light, subpycnocline waters in the estuary (Tyler and Seliger, 1978 , 1981). This dinoflagellate species appears to be physiologically well-adapted to survive prolonged periods of time at light levels unsuitable for most phytoplankton species. For this reason, and to elucidate the photosynthetic responses of phytoplankton grown in a varying light supply, the studies described here were undertaken.

\section{MATERLALS AND METHODS}

\section{The 'wheel'}

The 'wheel' (Fig. 1) consists of 24 compartments for batch cultures, arranged as rays in a 4 -foot diameter circle. This device overlies a light source, with irradiance provided by cool white fluorescent lamps. Between the culture compartments and the light source is a mechanical shade that is attached by an axle through precision bearings to a $24 \mathrm{~h}$ interval timer. The geometry of the shade is variable. As currently arranged, half of the shade is opaque, giving a 


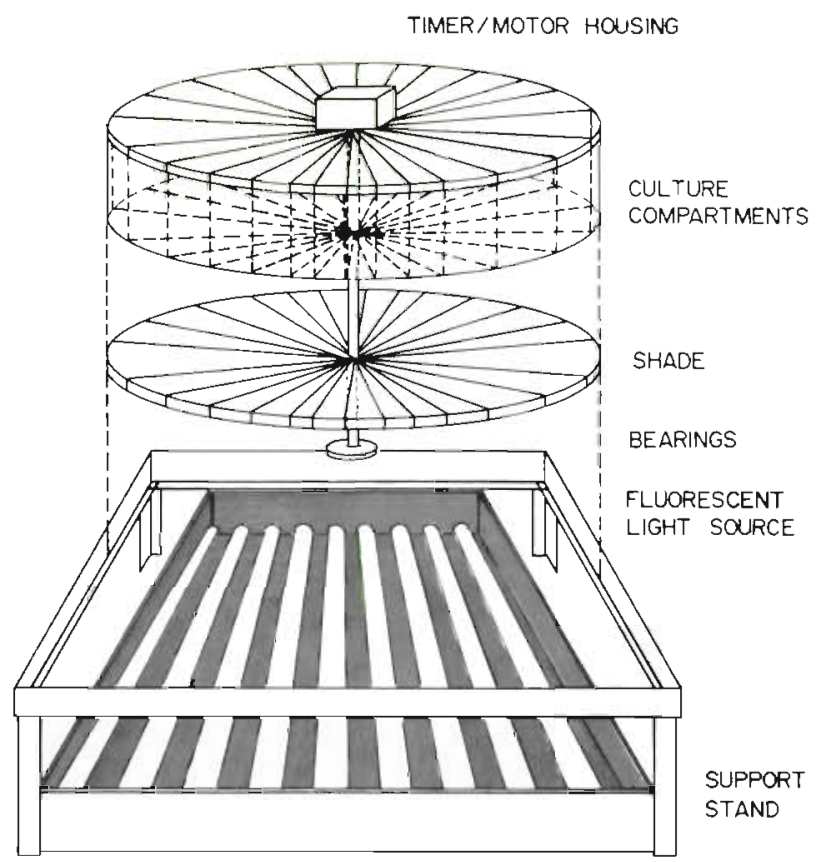

Fig. 1. Diagrammatic view of the 'wheel' culture device showing the major components. There are 24 compartments overlying a fluorescent light source. Between the culture compartments and the light source is a shade which rotates at 1 revolution $\mathrm{d}^{-1}$ on an axle driven by an interval timer. The shade is configured with half its compartments opaque and half fitted with neutral density screens to provide variations in light intensity to each compartment as the shade rotates. Each culture compartment has a plexiglass shelf which supports up to four $250 \mathrm{ml}$ cultures, giving a capacity of $24 \mathrm{l}$ for the entire culture device

$12 \mathrm{~h}$ light, $12 \mathrm{~h}$ dark (LD 12:12) cycle. The transparent portions of the shade are fitted with neutral density screens in a sequentially decreasing, then increasing number of layers, providing a continuous range of light intensities to simulate changes in sunlight intensity during a day. The light cycle provided on the 'wheel' using the current configuration of screens on the shade is depicted in Fig. 2A. By placing additional screens in each compartment, the light cycle can be easily modified to reduce the total irradiance but retain variations in intensity (Fig. 2B, C).

Preliminary experiments were conducted with the red-tide dinoflagellate Gonyaulax polyedra to enable a comparison of rhythms in bioluminescence and photosynthesis as determined using the 'wheel' to the patterns determined at the same time using a more conventional sampling protocol. Results of these control experiments (Figs. 3, 4) documented the usefulness of the new approach for phasing replicate cultures to distinct light-dark schedules. Rhythms in luminescence and photosynthetic capacity $\left(\mathrm{P}_{\max }\right)$ showed identical patterns using either time-lagged replicates from the 'wheel' or single cultures.

\section{Cultures}

Batch cultures of Prorocentrum mariae-lebouriae (isolated by $\mathrm{M}$. Tyler from a 1979 bloom in the Chesapeake Bay) were grown in ' $\mathrm{f} / 2^{\prime}$ medium at $15^{\circ} \mathrm{C}$ (Guillard and Ryther, 1962) using as the base sterile filtered Atlantic Ocean water diluted with distilled water to $15 \% \mathrm{~S}$. Stock cultures for inoculation into experimental flasks were grown in 2.81 Fernbach flasks to mid-exponential phase $\left(=4 \times 10^{4}\right.$ cells ml $\left.{ }^{-1}\right)$ on LD 12:12. This stock was diluted to an initial cell density of 500 cells $\mathrm{ml}^{-1}$, mixed, and $200 \mathrm{ml}$ aliquots were dispensed to twenty-four $250 \mathrm{ml}$ Erlenmeyer culture flasks. One of these cultures was placed in each compartment on the 'wheel' and allowed to grow for $7 \mathrm{~d}$ prior to the experiment; $24 \mathrm{~h}$ were required to phase a culture to the distinct light-dark schedule that was provided to each compartment. The initial light cycle provided 5.4 $\mathrm{E} \mathrm{m}^{-2} \mathrm{~d}^{-1}$ to cultures (Fig. 2A), an equivalent integral amount of light as would be provided on $L D$ 12:12 with a constant light intensity of $125 \mu \mathrm{E} \mathrm{m}^{-2} \mathrm{~s}^{-1}$.

\section{Experimental design}

Aliquots of culture were harvested and the photoadaptation experiment initiated $7 \mathrm{~d}$ after inoculation. Six cultures were selected corresponding to circadian times $(=\mathrm{CT}) 0,3,6,9,12$ and 18 , where CT 0 is

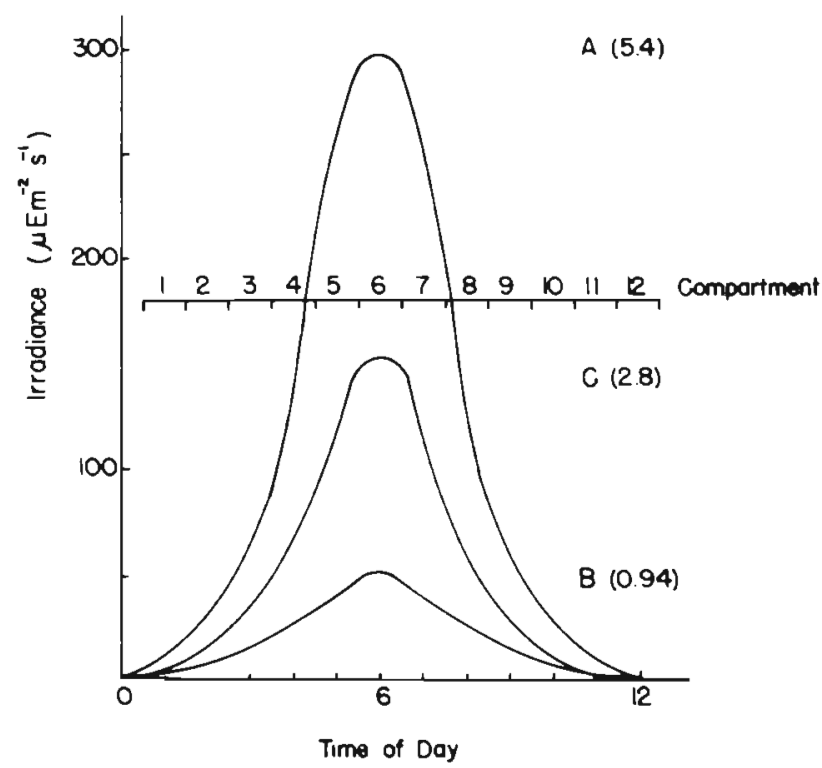

Fig. 2. The 3 light cycles used: Light cycle provided by the 'wheel' with (A) current shade configuration; (B) 1 additional layer of neutral density screens placed in each compartment; (C) 3 additional layers of screens. Values for integrated irradiance ( $P F D$ in $\mathrm{E} \mathrm{m}^{-2} \mathrm{~d}^{-1}$ ) provided in different parts of the experiment are presented adjacent to each light cycle plot 


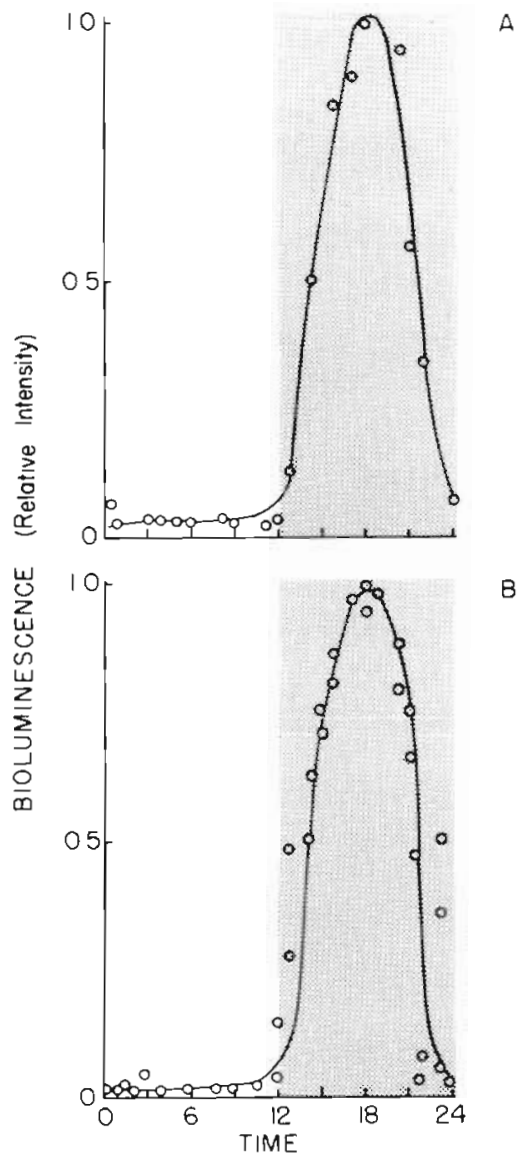

Fig. 3. Gonyaulax polyedra. Bioluminescence rhythm. (A) Conventional measurements of acid-excited light emission made around-the-clock on a single batch culture; $(B){ }_{1} \mathrm{dnd}_{1}$ vidually phased cultures grown on the 'wheel' and measuring their luminescence simultaneously. Methods used for measuring $G$. polyedra luminescence are described in Sweeney and Hastings (1957). Shaded areas: dark perıods on LD $12: 12$

equivalent to the onset of the light period. Using the 'wheel', cultures representing all circadian times were available simultaneously. The position of the leading edge of the shade (dawn) dictated which compartment corresponded to a particular CT at any time durng the day. Cultures from the selected compartments were subdivided for determining the photosynthesisirradiatice (P-I) relationship, cellular pigment concentrations, carbon and nitrogen content, cell numbers, growth rate $\left(\mu_{\text {cell }}\right)$, and turnover of carbon $\left(\mu_{C}\right)$. These methods are discussed individually in subsequent sections.

Following the harvesting of representative cultures from individual 'wheel' compartments, a light shift was effected wherein 3 layers of neutral density screens were added to each compartment underlying the Prorocentrum cultures. This addition of screens reduced the total light received by each culture to $0.94 \mathrm{E} \mathrm{m}^{-2}$ $\mathrm{d}^{-1}, 17.3 \%$ of that provided with the original LD cycle (Fig. 2B), and equivalent to the integral light that would be provided on LD 12:12 using a single intensity of $21.8 \mu \mathrm{E} \mathrm{m} \mathrm{m}^{-2} \mathrm{~s}^{-1}$. Three days (72 h) following this reduction in light availability, measurements of the P-I relationship, cell pigment concentrations, $C$ and $N$ content, and cell numbers were again made. Cultures were harvested from compartments representing the same CT's as were sampled in the first run. After completing the second set of measurements, 2 layers of screening were removed from each compartment and the light ayailability increased to $51.9 \%$ (Fig. 2C) of the integral irradiance supplied by the original screen configuration. A constant light intensity of $64.8 \mu \mathrm{E} \mathrm{m}^{-2}$ $\mathrm{s}^{-1}$ on LD 12:12 would provide an equivalent $2.8 \mathrm{E} \mathrm{m}^{-2}$ $\mathrm{d}^{-1}$ as did the light regime of cycle C. After $4 \mathrm{~d}(96 \mathrm{~h})$ in this new light environment, cells were again harvested from cultures at CT $0,3,6,9,12$ and 18 . Measurements of photosynthesis, pigmentation, $\mathrm{C}$ and $\mathrm{N}$ content, and cell numbers were made as before.

\section{Photosynthesis-irradiance (P-I) relationship}

Photosynthesis was measured using the radioactive carbon $\left({ }^{14} \mathrm{C}\right)$ assimilation method (Steeman Nielsen, 1952; Strickland and Parsons, 1968), modified for use with laboratory cultures. Ten $\mathrm{ml}$ samples of culture were incubated for 1 to $2 \mathrm{~h}$ at a range of irradiances with $0.1 \mu \mathrm{Ci}{ }^{14} \mathrm{C}$-sodium bicarbonate added in $100 \mu \mathrm{l}$ doses. At the end of an incubation, cells were collected on Gelman $\mathrm{A} / \mathrm{E}$ glass fiber filters at low vacuum pressure ( $=150 \mathrm{~mm} \mathrm{Hg}$ ), rinsed with $10 \mathrm{ml}$ of filtered $15 \% \mathrm{~S}$ water, carefully acidified with a drop or two of $0.1 \mathrm{~N} \mathrm{HCl}$ to remove residual inorganic ${ }^{14} \mathrm{CO}_{2}$, and placed in liquid scintillation (LS) minivials containing $3.5 \mathrm{ml}$ of toluene-base LS cocktail (M1 + Triton X100). Samples were counted on a Packard Tri-Carb model 3320 LS counter and their activities determined using the channels-ratio method.

Incubation intensities were controlled with layers of neutral density screens placed between the samples and a light source that consisted of four high output (1500 ma) cool white fluorescent lamps. A total of 12 light levels was used and dark controls were run concurrently. The light bank on which P-I curve incubatrons were conducted is housed in a walk-in environmental chamber set at $15^{\circ} \mathrm{C}$. Local heating caused by lamp and ballast output was dissipated by a pair of fans.

Irradiance (photon flux density $=$ PFD) was measured using a Licor model 185 quantum meter which was calibrated for the light sources we used. All values for PFD were corrected from meter readings (in $\mu \mathrm{E} \mathrm{m}^{-2}$ $\mathrm{s}^{-1}$ ) to photon flux based on the meter's response to the 
light source, and converted back to actual flux $\left(1 \mathrm{E}=6.02 \times 10^{23}\right.$ photons) expressed in $\mu \mathrm{E} \mathrm{m}^{-2} \mathrm{~s}^{-1}$ for ease of comparison with other work. Integrated PFD on the 'wheel' was determined by attaching a strip chart recorder to the quantum meter and recording irradiance throughout the light cycle. Charts were integrated planimetrically to give values for the total light supplied with the combination of screens on the shade (Cycle A), and with additional neutral density screens that were used to give reduced PFD during the experiment (Cycles B and C).

Data for photosynthesis-irradiance (P-I) curves were processed and plotted using an Apple II microcomputer and peripherals. Photosynthetic rates were normalized to both chlorophyll $a$ and cell numbers. Calculations of P-I curve parameters were made by simultaneous parameter estimation on a DEC 10 computer terminal using methods of Platt et al. (1980) for determining $\alpha$ and $P_{\max }$ from $P$ and I data fit to a hyperbolic tangent function.

\section{Total $\mathrm{CO}_{2}$}

Total $\mathrm{CO}_{2}$ was measured by a gas-stripping and capture method, using a Beckman model 864 Infrared Gas Analyzer. The ' $\mathrm{f} / 2$ ' medium at $15 \% \mathrm{~S}$ we used to culture Prorocentrum had $\mathrm{tCO}_{2}=1.5 \mathrm{mM}$.

\section{Photosynthetic pigments}

At each of the 3 sampling times, aliquots of Prorocentrum cultures were gently filtered onto $0.4 \mu$ pore size, $47 \mathrm{~mm}$ diameter Nuclepore filters, quick frozen on dry ice, and stored for later analysis. These samples were analyzed for chlorophylls, carotenoids, and xanthophylls using the thin layer chromatographic (TLC) techniques described by Jeffrey $(1968,1974)$. Seventy-five to $100 \mathrm{ml}$ of culture were required for each replicate in the TLC analyses. Cell counts were made from a small aliquot and pigment values expressed on a per cell basis. A Beckman model 25 recording spectrophotometer was used to analyze the extracts and samples eluted by TLC.

\section{Cell numbers and growth rates}

Prorocentrum in 'wheel' cultures were counted throughout the experiment using a $0.1 \mathrm{ml}$ PalmerMaloney counting chamber. The average growth rate $\left(\mu_{\text {cell }}\right)$ was calculated as the mean of growth rates in 8 individual cultures sampled from different compartments on the 'wheel'. Cultures were in log phase

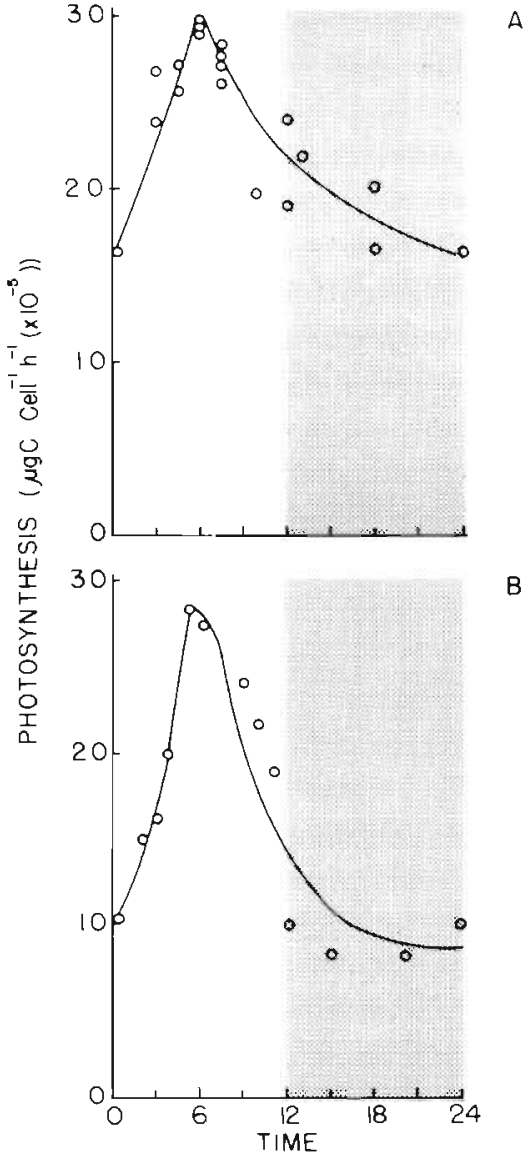

Fig. 4. Gonyaulax polyedra. Photosynthetic capacity $\left(\mathrm{P}_{\max }\right)$ rhythm (A) Conventional measurements of light-saturated ${ }^{14} \mathrm{C}$-bicarbonate assimilation made around-the-clock on a single batch culture; (B) photosynthetic carbon incorporation in aliquots from cultures phased to distinct light-dark schedules on the 'wheel'

throughout the entire study and were grown in nutrient conditions which were non-limiting, so reductions in $\mu_{\text {cell }}$ represented light-mediated changes. The maxImum cell density that Prorocentrum achieves is nearly 5 times that reached at any time during the experiment, therefore age of the cultures (Harding et al., 1981b; Prézelin, in press) was not a factor controlling the physiological response.

\section{Carbon and nitrogen content}

From Prorocentrum cultures, $25 \mathrm{ml}$ were filtered onto pre-combusted $\left(400^{\circ} \mathrm{C}, 24 \mathrm{~h}\right) 25 \mathrm{~mm}$ diameter Gelman A/E glass fiber filters with a Swinex cartridge and disposable syringe. These filters were desiccated at $70^{\circ} \mathrm{C}$ in a drying oven before analyzing for $\mathrm{C}$ and $\mathrm{N}$ content using a Perkin Elmer model 240B elemental analyzer. Cell counts were performed at the same time 
samples were filtered and $\mathrm{C}$ and $\mathrm{N}$ per cell were calculated from these data.

\section{Turnover of carbon $\left(\mu_{C}\right)$}

The turnover of carbon $\left(\mu_{C}\right)$ was estimated using P-I curve parameters, data on light availability for each experimental condition, and respiration values from oxygen consumption in the dark at $15{ }^{\circ} \mathrm{C}$, converted to carbon units with a respiratory quotient (RQ) of 1.2 (data from Meeson and Faust, in prep.).

\section{RESULTS AND DISCUSSION}

\section{Photosynthesis-irradiance (P-I) relationship}

Diel periodicity of the P-I relationship was detected for Prorocentrum mariae-lebouriae (Figs. 5, 6). Oscillations in both $\alpha$ and $P_{\max }$ occurred on both per cell and per chl a bases (Table 1), and were comparable to those described earlier for cultures of dinoflagellates (Prézelin and Sweeney, 1977; Prézelin et al., 1977; Meeson, 1981; Harding et al., 1981a), and for natural phytoplankton assemblages (MacCaull and Platt, 1977; Prézelin and Ley, 1980; Harding et al., 1982a, b;
Malone, 1982). On the original LD cycle (Fig. 2A), $\alpha$ and $\mathrm{P}_{\max }$ showed photosynthetic periodicity with an amplitude of approximately 1.4 to 1.6 in the daylight hours, as measured by the maximum to minimum ratio (Table 1; Figs. 5, 6). Photosynthetic periodicity persisted following the shift to low light (A to $B$ ), but the amplitude of $\alpha$ and $P_{\max }$ oscillations increased, ranging from 2.3 to 2.5. Upon exposure to intermediate light ( $B$ to C), P-I curve periodicity continued at an amplitude of 1.8 to 2.0 . When $\alpha$ and $P_{\max }$ measured at CT 18 (middle of the dark period) were considered in calculating the amplitude, values ranged from 3.6 to 4.7 in A, 1.9 to 2.3 in B, and 1.9 to 2.0 in C. This finding is consistent with the relationship between amplitude and physiological state reported earlier for the diatom, Ditylum brightwellii (Harding et al., 1981b).

The time of occurrence of maximum $\alpha$ and $P_{\max }$ values changed following the shift to low light. On light cycle A (high light), the maximum values of $\mathrm{P}-\mathrm{I}$ curve parameters occurred at CT 3 (mid-morning), similar to results for diatom species grown in nutrientsufficient conditions (Harding et al., 1981a). The maxima in P-I curve parameters after the shift to light cycle $B$ (low light) occurred at CT 6 (midday). $\alpha$ and $P_{\max }$ also peaked at CT 6 following the shift to light cycle $C$ (intermediate light). The amplitudes of P-I curve oscillations for Prorocentrum mariae-lebouriae and the
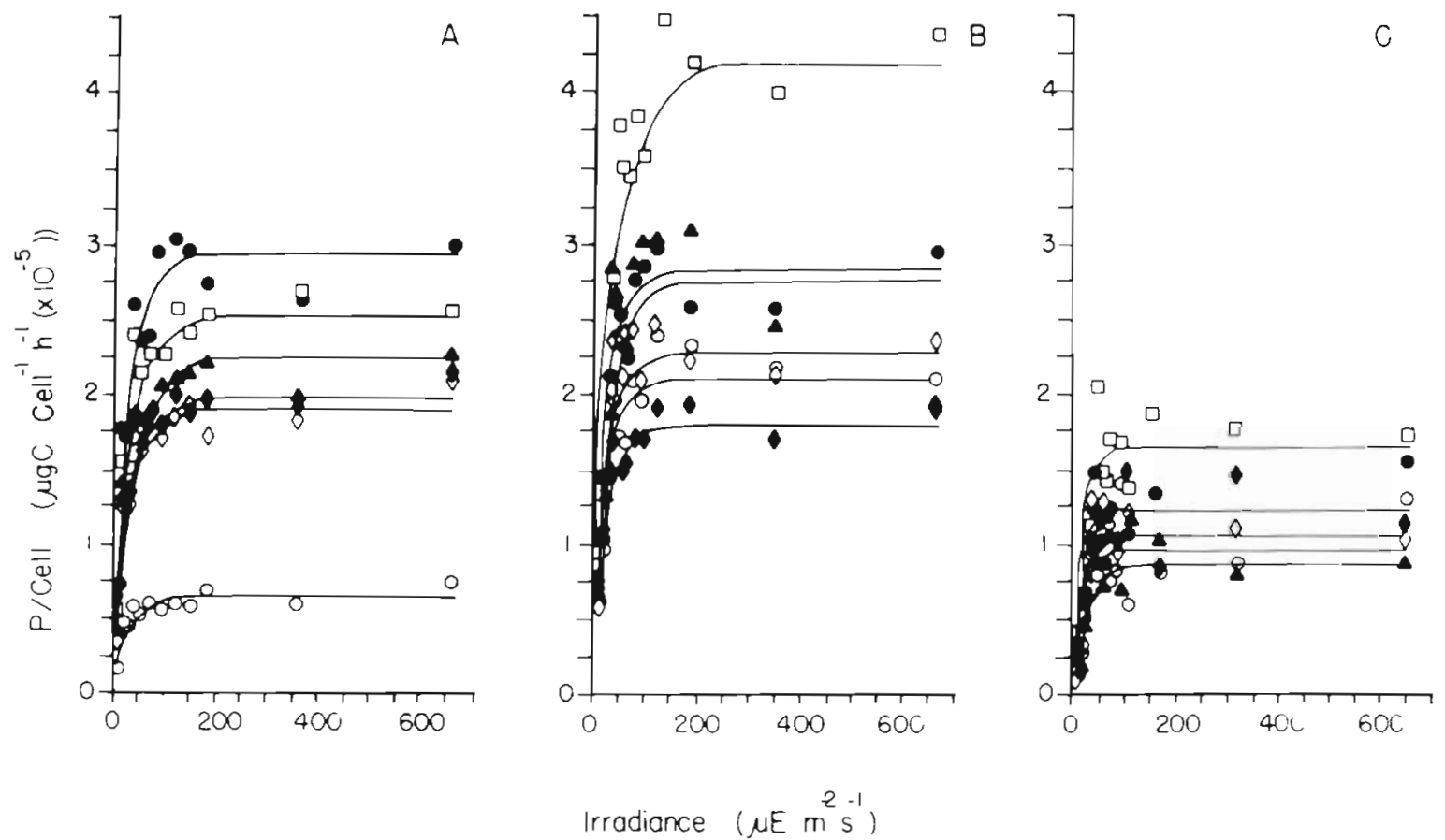

Fig. 5 (A-C). Prorocentrum mariae-lebouriae. Photosynthesis-irradiance (P-I) curves on a per cell basis for cells grown on the 'wheel' The separate figures depict results from each part of the light-shift experiment, with letter designations corresponding to the light cycles in Fig. 2. Six compartments were sampled for photosynthesis measurements on each sampling day. The circadian times (CT's) represented are: CT $0(\Delta)$, CT $3(\bullet)$, CT $6(\square$, CT $9(\diamond)$, CT $12(\bullet)$, and CT $18(0)$. Values for the derived parameters dre presented in Table 1 
Table 1. Prorocentrum mariae-lebouriae. Parameters of photosynthesis-irradiance (P-I) relationship on per cell and per chiorophyll a bases as determined at 6 circadian times for each photic environment during light shift experiment. Standard error (SE) for each parameter indicated in parentheses; $n=$ number of $P$-l curve points used in the simultaneous parameter estimation to determine $\alpha$ and $P_{\max }$

\begin{tabular}{|c|c|c|c|c|c|c|c|}
\hline \multirow{2}{*}{\multicolumn{2}{|c|}{$\begin{array}{l}\text { Light cycle } \\
\left(\mathrm{E} \mathrm{m}^{-2} \mathrm{~d}^{-1}\right)\end{array}$}} & \multirow[b]{2}{*}{$\mathrm{CT}$} & \multirow[b]{2}{*}{$\mathrm{n}$} & \multicolumn{2}{|c|}{ Per cell } & \multicolumn{2}{|c|}{ Per chlorophyll } \\
\hline & & & & $\begin{array}{c}\alpha \\
\left(\mu g C \text { cell } 1^{-1} \mathrm{~h}^{-1}\right. \\
\left.\mu \mathrm{E}^{-1} \mathrm{~m}^{2} \mathrm{~s}\left[\times 10^{-7}\right]\right)\end{array}$ & $\begin{array}{c}\mathrm{P}_{\max } \\
\left(\mu \mathrm{gCcel]^{-1 }} \mathrm{h}^{-1}\right. \\
\left.\left[\times 10^{-5}\right]\right)\end{array}$ & $\begin{array}{c}\alpha \\
\left(\mu g C \mu g C h a^{-1} h^{-1}\right. \\
\left.\mu E^{-1} m^{2} s\right)\end{array}$ & $\underset{\left(\mu g C \mu g C h l a^{-1} h^{-1}\right)}{P_{\max }}$ \\
\hline \multirow[t]{6}{*}{ A } & 5.4 & 0 & 12 & $4.92( \pm 0.107)$ & $2.12 \quad( \pm 0.014)$ & $0.193( \pm 0.004)$ & $8.30( \pm 0.054)$ \\
\hline & & 3 & 12 & $6.71( \pm 0.184)$ & $2.86 \quad( \pm 0.026)$ & $0.263( \pm 0.007)$ & $11.20( \pm 0.139)$ \\
\hline & & 6 & 12 & $5.96( \pm 0.125)$ & $2.52( \pm 0.017)$ & $0.234( \pm 0.005)$ & $9.88( \pm 0.067)$ \\
\hline & & 9 & 12 & $4.93( \pm 0.129)$ & $1.85( \pm 0.014)$ & $0.193( \pm 0.005)$ & $7.26( \pm 0.056)$ \\
\hline & & 12 & 12 & $5.15( \pm 0.110)$ & $1.94 \quad( \pm 0.012)$ & $0.202( \pm 0.004)$ & $7.59( \pm 0.048)$ \\
\hline & & 18 & 12 & $1.89( \pm 0.077)$ & $0.607( \pm 0.006)$ & $0.074( \pm 0.003)$ & $2.38( \pm 0.025)$ \\
\hline \multirow[t]{6}{*}{$\mathrm{B}$} & 0.94 & 0 & 12 & $8.08( \pm 0.421)$ & $2.79 \quad( \pm 0.041)$ & $0.158( \pm 0.008)$ & $5.45( \pm 0.081)$ \\
\hline & & 3 & 12 & $7.65( \pm 0.217)$ & $2.80 \quad( \pm 0.023)$ & $0.150( \pm 0.005)$ & $5.47( \pm 0.046)$ \\
\hline & & 6 & 12 & $9.66( \pm 0.266)$ & $4.12 \quad( \pm 0.038)$ & $0.189( \pm 0.005)$ & $8.05( \pm 0.075)$ \\
\hline & & 9 & 12 & $8.02( \pm 0.226)$ & $2.29 \quad( \pm 0.016)$ & $0.157( \pm 0.004)$ & $4.47( \pm 0.031)$ \\
\hline & & 12 & 12 & $5.24( \pm 0.214)$ & $1.78 \quad( \pm 0.020)$ & $0.102( \pm 0.004)$ & $3.48( \pm 0.040)$ \\
\hline & & 18 & 12 & $5.22( \pm 0.173)$ & $2.17 \quad( \pm 0.024)$ & $0.102( \pm 0.003)$ & $4.23( \pm 0.046)$ \\
\hline & 2.8 & 0 & 12 & $3.39( \pm 0.284)$ & $0.946( \pm 0.019)$ & $0.110( \pm 0.009)$ & $3.05( \pm 0.061)$ \\
\hline & & 3 & 12 & $4.16( \pm 0.399)$ & $1.20 \quad( \pm 0.028)$ & $0.134( \pm 0.013)$ & $3.86( \pm 0.091)$ \\
\hline & & 6 & 12 & $4.68( \pm 0.279)$ & $1.69 \quad( \pm 0.030)$ & $0.151( \pm 0.009)$ & $5.46( \pm 0.096)$ \\
\hline & & 9 & 12 & $3.21( \pm 0.367)$ & $1.04 \quad( \pm 0.032)$ & $0.103( \pm 0.012)$ & $3.36( \pm 0.102)$ \\
\hline & & 12 & 12 & $4.07( \pm 0.272)$ & $1.20 \quad( \pm 0.020)$ & $0.131( \pm 0.009)$ & $3.86( \pm 0.065)$ \\
\hline & & 18 & 12 & $2.30( \pm 0.184)$ & $0.877( \pm 0.021)$ & $0.074( \pm 0.006)$ & $2.83( \pm 0.069)$ \\
\hline
\end{tabular}

time of occurrence of daily photosynthetic maxima are similar to those reported for other phytoplankton species (cf. Sournia, 1974; Prézelin and Sweeney, 1977; Harding et al., 1981a, b).

A comparison of $\alpha$ and $P_{\max }$ per chl a before and after the shift to low light ( $A$ to $B$ ) shows a reduction in both parameters, while per cell values were greater after the shift (Table 1). The change in per cell P-I curves was reversed following the shift to higher light ( $B$ to $C$ ), but $\alpha$ and $\mathrm{P}_{\max }$ per chl continued to decline. This pattern of change in $P$ per chl vs. I in response to low light corresponds to a PSU 'size' strategy according to Prézelin and Sweeney (1979). In contrast, the changes in $\mathrm{P}$ per cell vs. I curves for Prorocentrum mariaelebouriae resemble shifts that are diagnostic of an increase in PSU 'number' (see also Prézelin, 1981). This apparent conflict in the interpretation of P-I curve results using the PSU 'size' and 'number' scheme makes it difficult to assign the response of $P$. mariaelebouriae to one of the strategies. This problem will be clarified by examining changes in pigment and carbon content associated with the P-I curve changes.
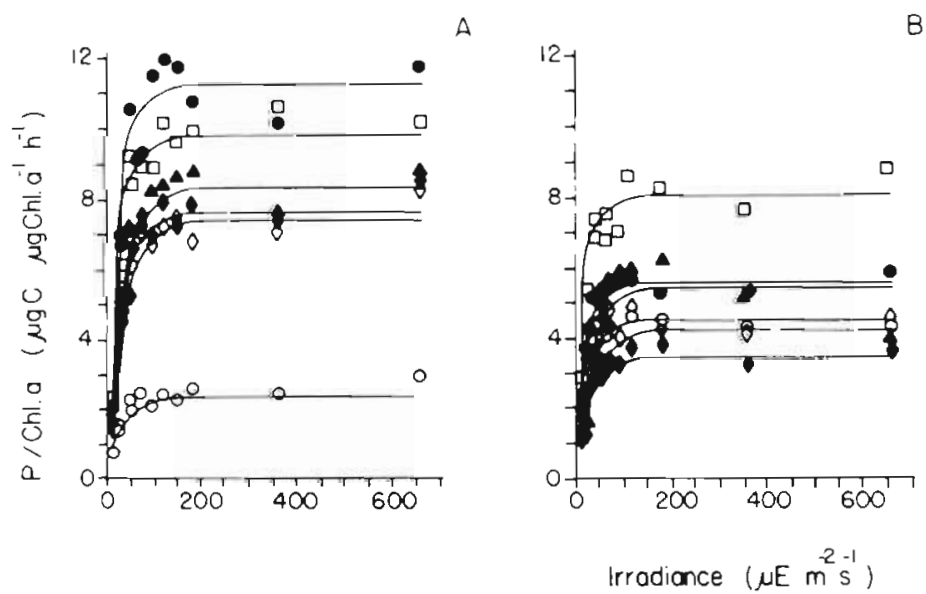

B

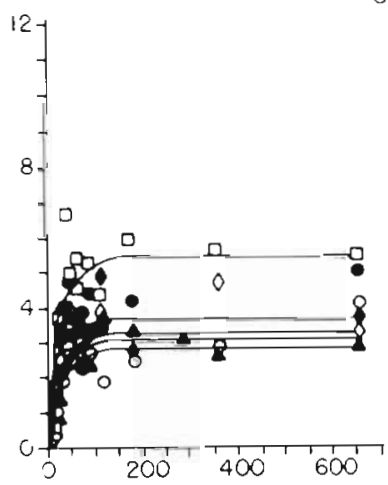

Fig. 6 (A-C). Prorocentrum mariae-lebouriae. P-I curves on a per chl a basis for P. $m-1$. For details see the legend to Fig. 5 . Values for the derived parameters are presented in Table 1 


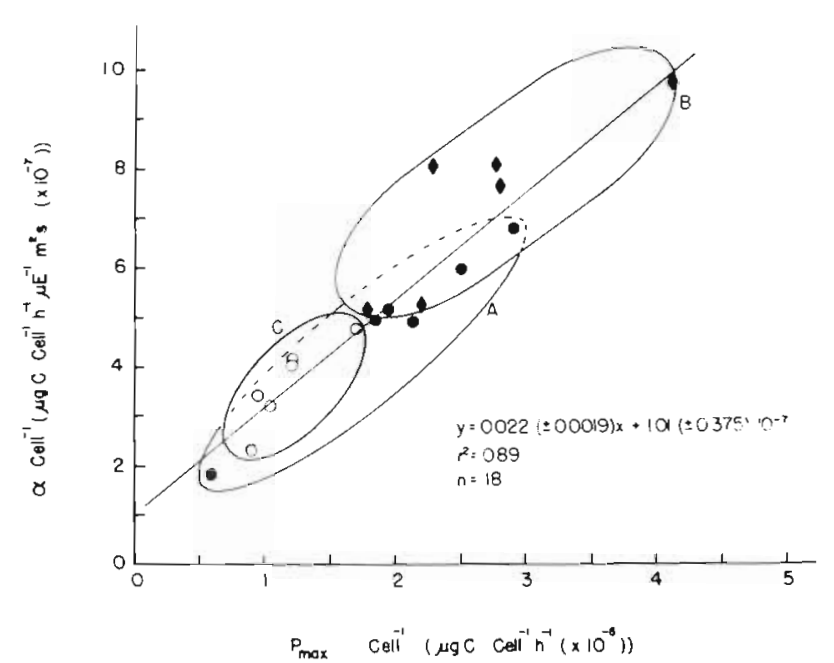

Fig. 7. Prorocentrum mariae-lebouriae. Per cell $\alpha$ versus $P_{\max }$ plots for the 3 parts of the light-shift experiment. The distinct symbols correspond to $\alpha-P_{\max }$ pairs from each part: $(\mathrm{A})-(\bullet)$; (B) $-(\bullet)$; (C) $-(O)$. Ellipses are used to enclose points from each part of the experiment to facilitate a comparison of the range of $\alpha-P_{\max }$ variations attributable to diel oscillations with shifts in that range accompanying a change in the photic environment. Linear regression of $\alpha$ versus $P_{\max }$ values for each part of the experiment and analyses of covariance on the regression coefficients revealed no significant difference in the slope between sampling times. Regression line and equation for pooled per cell data $( \pm S E)$ are presented

An important finding for Prorocentrum mariaelebouriae demonstrates that changes in $\alpha$ and $\mathrm{P}_{\max }$ values associated with diel periodicity, on both per cell and per chl bases, are greater than or equal to the maximum changes in these parameters accompanying photoadaptation (Beardall and Morris, 1976; Prézelin

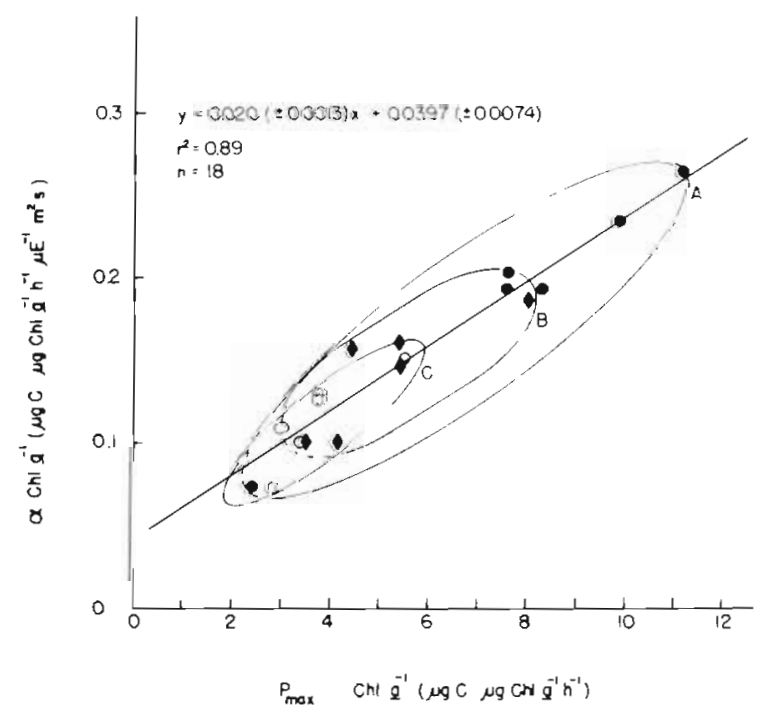

Fig. 8. Prorocentrum mariae-lebouriae. Per chl a a versus $P_{\text {max }}$ plot. Details described in Fig. 7 legend. No significant differences in slopes of individual regressions of a versus $P_{\max }$ were detected; line and equation for pooled per chl a data ( \pm SE) are presented and Sweeney, 1978; Falkowski, 1980; Prézelin and Matlick, 1980). Together with the fact that maxima in P-I curve parameters for $P$. mariae-lebouriae occur at different times of the day under different light conditions, there emerges a strong argument for considering the importance of periodicity in $\alpha$ and $\mathrm{P}_{\max }$ when studying photoadaptation.

The parameters of $P$ per cell and $P$ per chl vs. I curves (Table 1) were grouped by photic regime and plotted in Figs. 7 and 8. Two-way ANOVA demonstrated significant differences $(P<.01)$ in $\alpha$ and $P_{\max }$ values for the three photic regimes (treatments $=$ light cycles $\mathrm{A}$, $B$, and $C$ ). The within-day (blocks = different circadian times) differences were also significant $(\mathrm{P}<.05)$ (see Table 2 for ANOVA results). Linear regressions of $\alpha$ vs. $P_{\max }$ plots and analyses of covariance on their regression parameters revealed no significant differ-

Table 2. Prorocentrum mariae-lebouriae. ANOVA Tables for P-I curve parameters $\alpha$ and $P_{\max }$. Treatments $=$ light Cycles $A$, $B$, and $C_{;}$blocks $=$circadian times $(C T) 0,3,6,9,12$, and 18 . $\cdot$ - P .05, $\cdots-$ P.01

\begin{tabular}{|c|c|c|c|c|c|}
\hline & & $\mathrm{df}$ & SS & MS & $F$ \\
\hline \multirow[t]{4}{*}{$\alpha$} & Total & 17 & 74.2 & & \multirow{4}{*}{$\begin{array}{r}23.4^{\circ} \\
5.29^{\circ}\end{array}$} \\
\hline & Treatments & 2 & 41.8 & 20.9 & \\
\hline & Blocks & 5 & 23.6 & 4.71 & \\
\hline & Error & 10 & 8.91 & 0.89 & \\
\hline \multicolumn{6}{|c|}{$\mathrm{P}_{\max }$} \\
\hline & Total & 17 & 13.5 & & \\
\hline & Treatments & 2 & 6.77 & 3.39 & \multirow{3}{*}{$\begin{array}{c}14.7 \\
3.85\end{array}$} \\
\hline & Blocks & 5 & 4.43 & 0.89 & \\
\hline & Error & 10 & 2.30 & 0.23 & \\
\hline
\end{tabular}

ences in the relationships between slope and asymptote of P-I curves from different parts of the experiment. The distributions of $\alpha$ and $P_{\max }$ pairs differed, however, as documented by the results of ANOVAs, indicating that both parameters changed in concert as a function of changes in the light environment.

The absence of a significant difference in the slopes of $\alpha$ vs. $\mathrm{P}_{\max }$ plots for different photic environments argues that changes in the absolute magnitude of these P-I parameters, as distinguished from changes in the relationship of $\alpha$ to $P_{\max }$, accompanied the light shift. This demonstrates the lack of a change in the halfsaturation irradiance $\mathrm{I}_{\mathrm{s}}$ (termed $\mathrm{I}=\mathrm{P}_{\max } / 2$ by Prézelin and Matlick, 1980, $K_{I}$ by Rivkin et al., 1982b). The usefulness of this constant as a meaningful measure of photoadaptive state, therefore, appears to be limited as cells which photoadapt do not necessarily shift $\alpha$ relative to $\mathrm{P}_{\text {max }}$. Mathematically, the half-saturation light level is directly proportional to $\mathrm{P}_{\max } / \alpha$ and does not provide information which supplements a direct com- 
parison of the relative changes of light-limited $(\alpha)$ and light-saturated $\left(P_{\max }\right)$ photosynthetic rates. Since it is the range of $\alpha-P_{\max }$ pairs that changes following the light-shift, an enhancement of carbon fixation as compared to rates that would occur in 'unadapted' cells would be expected to result from improved utilization of low irradiances. This adaptation is better quantitated by the magnitude of the P-I curve slope $(\alpha)$ than by the several light-saturation constants which are simply derived from the ratio of $P_{\max }$ to $\alpha$.

\section{Photosynthetic pigments}

Prorocentrum mariae-lebouriae showed increases in chlorophyll (chl) a, chl $c$, and peridinin when shifted to low light (Table 3). Chl a per cell doubled within $72 \mathrm{~h}$ of the shift, showing a $96 \%$ increase from 2.6 to $5.1 \mathrm{pg}$ cell ${ }^{-1}$. Chl $c$ per cell increased $66 \%$ and peridinin per cell increased $39 \%$. The molar ratio for chl a: chl $c$ changed only slightly from 0.98 before the shift to 1.2 in low light, while the peridinin: chl a molar ratio was virtually unchanged. Part of the increase in chl a can be explained by increases in chl $c$ and peridinin which are associated with chl $a$ in pigment - protein complexes comprising the light harvesting component (LHC) (Prézelin, 1976; Boczar et al., 1980; Prézelin, 1981; in press). There are approximately 4 peridinin molecules for each chl a molecule in the peridinin-chl $a$-protein (PCP), and $5 \mathrm{chl} c$ 's for each chl $a$ in the chl a-chl-c-protein (Boczar et al., 1980; Prézelin, in press). Even when chl a values were corrected to eliminate that part of the change in chl a concentration associated with changes in PCP and a-c-protein levels, however, only subtle changes in pigment molar ratios were found (Table 3). According to the PSU 'size' and 'number' scheme presented by Prézelin and Sweeney (1979) and Prézelin (in press), the relatively constant molar ratios for pigment concentrations in $P$. mariaelebouriae would be interpreted as a photoadaptive strategy involving increased 'numbers' of PSU's per cell.

\section{Photosynthetic performance}

The improvement in photosynthesis resulting from a photoadaptive strategy can be quantitated by comparing photosynthetic performance prior to and following a light shift. Photosynthetic performance $\left(\mathrm{P}_{\mathrm{i}}\right)$ is the rate of photosynthesis that occurs in situ in the light conditions in which cells are grown. Usually this approach has been applied with single midday $\mathrm{P}_{\mathrm{i}}$ determinations in experiments using constant light intensities (cf. Prézelin and Sweeney, 1978). In experimental conditions that use varying light intensities and with organisms that exhibit photosynthetic rhythms, such an approach is oversimplified. Photosynthetic performance must be calculated using empirically-determined light values to incorporate variations in intensity, and must encompass the daylight period to account for photosynthetic rhythmicity. Taking this approach, a measure of the enhancement of photosynthetic performance per day in 'adapted' cells can be obtained by combining the range of P-I curve parameters determined for 'unadapted' cells with irradiance data for the low light regime. By comparing 'unadapted' photosynthetic performance rates calculated in this way to rates in 'adapted' cells, a measure of the improvement in carbon assimilation associated with photoadaptation is acquired.

Photosynthetic performance (net) for Prorocentrum mariae-lebouriae on light cycles $A$ and $B$ was $1.3 \times 10^{-4} \mu \mathrm{g} \mathrm{C}$ cell $^{-1} \mathrm{~d}^{-1}$ (Table 4). This equality reflects the successfulness of the increased pigment content and improved light harvesting efficiency fol-

Table 3. Prorocentrum mariae-lebouriae. Concentrations of photosynthetic pigments and pigment ratios during light shift experiment. Pigment ratios based on whole cell molar concentrations of $c h l a_{1}$ chl $c$, and peridinin, and on pigment levels corrected for chl a content in pigment-protein complexes involving chl $c$ and peridinin (in parentheses)

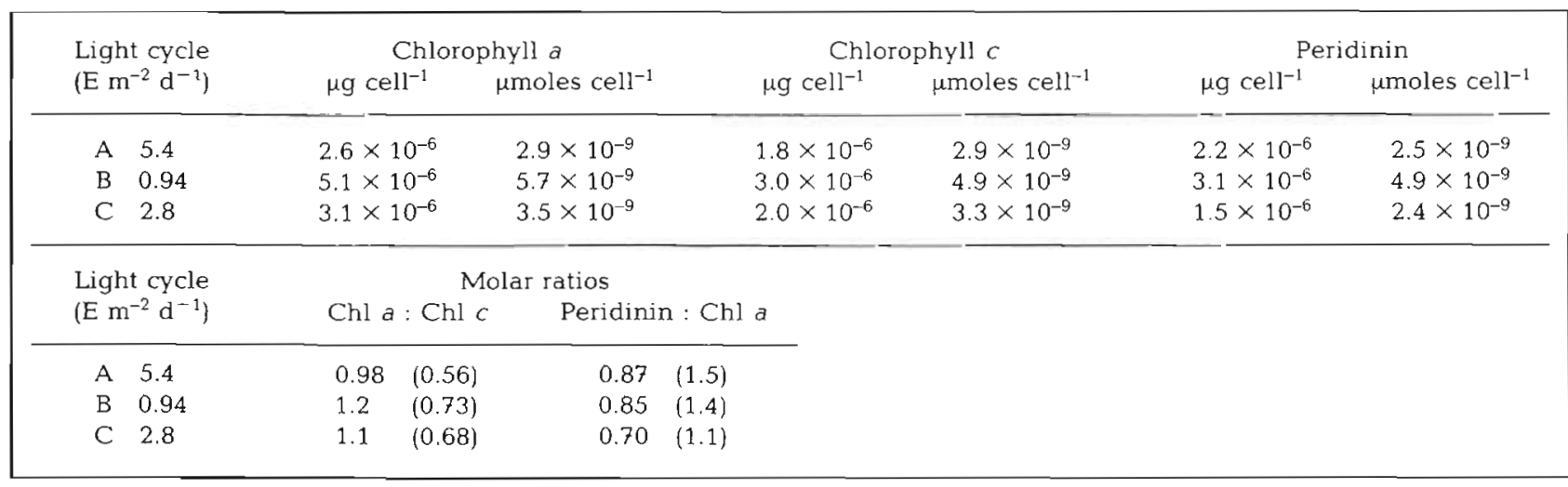


Table 4. Prorocentrum mariae-lebouriae. Net photosynthetic performance, growth rate, turnover of carbon, and carbon and nitrogen content during light shift experiment

\begin{tabular}{|c|c|c|c|c|c|c|}
\hline $\begin{array}{l}\text { Light cycle } \\
\left(E \mathrm{~m}^{-2} \mathrm{~d}^{-1}\right)\end{array}$ & $\underset{\left(\mu g C \text { cell }^{-1} d^{-1}\right)}{\int P_{i}-\int R_{1}}$ & $\begin{array}{c}\mathrm{C} \mathrm{cell} \mathbf{l}^{-1} \\
\left(\mathrm{pg} C \mathrm{cell}^{-1}\right)\end{array}$ & $\begin{array}{l}\mu_{c e l l} \\
\left(d^{-1}\right)\end{array}$ & $\begin{array}{l}\mu_{C} \\
\left(d^{-1}\right)\end{array}$ & $\begin{array}{c}N \text { cell }^{-1} \\
\left(\mathrm{pg} N \text { cell }^{-1}\right)\end{array}$ & $\begin{array}{l}C: N \\
(w t)\end{array}$ \\
\hline A 5.4 & $1.3 \times 10^{-4}$ & 340 & 0.46 & 0.39 & 45 & 7.6 \\
\hline B 0.94 & $1.3 \times 10^{-4}$ & 214 & -0.02 & 0.61 & 19 & 11 \\
\hline C 2.8 & $0.29 \times 10^{-4}$ & 97 & 0.26 & 0.30 & 15 & 6.6 \\
\hline
\end{tabular}

lowing the shift to low light. By comparison, 'unadapted' photosynthetic performance calculated using P-I curve parameters from light cycle $A$ and irradiance values from light cycle $B$ was only $0.59 \times 10^{-4} \mu \mathrm{g} \mathrm{C}$ cell ${ }^{-1} \mathrm{~d}^{-1}$. This analysis indicates an improvement of $55 \%$ in daily carbon assimilation. Enhanced carbon assimilation following the change in photic regime is largely associated with an increase in the light-limited portion of $\mathrm{P}$ per cell vs. I curves ( $\alpha$ cell ${ }^{-1}$ ) and an increased efficiency for using the light levels supplied in Cycle B.

This measure of the improvement in photosynthetic performance associated with light adaptation clearly demonstrates the ability of enhanced carbon fixation in low light to counter reduced light availability. Complete analysis should consider the possible effect of previous light history on rates of respiration (Dubinsky and Falkowski, 1982), and on the extracellular release of recently fixed carbon (Glibert and Goldman, 1982). The approach used here, however, serves to provide a quantitative measure of photoadaptation which is more directly linked to the improvement of daily carbon assimilation than light saturation constants or single midday measurements of photosynthetic performance in constant conditions that have been used previously.

\section{Growth rates}

Despite the increase in photosynthetic efficiency due to increased pigment concentrations that occurred within $72 \mathrm{~h}$ of the reduction in irradiance, cell division ceased following the shift from high to low light (A to B). Prorocentrum mariae-lebouriae grown on the 'wheel' in high light (Cycle A) had a growth rate $\left(\mu_{\text {cell }}\right)$ of $0.46( \pm 0.016) \mathrm{d}^{-1}$. Following the shift to low light (Cycle B), $\mu_{\text {cell }}$ declined to $-0.02( \pm 0.017) \mathrm{d}^{-1}$, a growth rate not significantly different from zero. Upon exposure to an intermediate light level (Cycle C), $\mu_{\text {ceil }}$ increased to $0.27( \pm 0.019) \mathrm{d}^{-1}$. These rates correspond to generation times of $1.5,>80$, and $2.6 \mathrm{~d}$, respectively.

The cessation of cell division following the shift to low light represents a unique finding in that other dinoflagellate species that have been examined were able to maintain their growth rates in low light using photoadaptive strategies (e. g. Gonyaulax polyedra Prézelin and Sweeney, 1978; Rivkin et al., 1982a; Glenodinium sp. - Prézelin and Matlick, 1980). From these differences in results for Prorocentrum mariaelebouriae as compared to $G$. polyedra and Glenodinium sp., we infer that a different strategy was used in response to the decrease in light availability. Pigment and P-I curve adaptations undertaken by $P$. mariae-lebouriae were sufficient to permit equivalent photosynthetic performance (Table 4) following the shift to low light $\left(0.94 \mathrm{E} \mathrm{m}^{-2} \mathrm{~d}^{-1}\right)$ as occurred on high light $\left(5.4 \mathrm{E} \mathrm{m}^{-1} \mathrm{~d}^{-1}\right)$ by the time photosynthesis measurements were made $72 \mathrm{~h}$ after the shift. Cellular carbon content declined during that $72 \mathrm{~h}$ interval (Table 4), however, suggesting that a transition period probably occurred following the shift to low light during which adaptive changes were insufficient to support the same level of carbon assimilation in low light as occurred immediately before the shift. Such a transition period and its manifestations in cellular composition point out the temporal specificity of a photoadaptive strategy. Further study is underway to document the time courses of each component in the overall strategy, and to define the duration of growth rate cessation.

Evidence in support of phytoplankton cells using a combination of photoadaptive changes in photosynthetic performance, carbon content, and pigmentation comes from the recent findings with Gonyaulax polyedra. Rivkin et al. (1982a) showed that G. polyedra maintained a maximal growth rate for several days following a shift to low light without implementing one of the pigment-based strategies involving PSU changes. Cells continued growing at $\mu_{\max }$ for several days in a suboptimal light environment by sacrificing carbon stores in lieu of changing pigmentation. Results with Prorocentrum mariae-lebouriae and $G$. polyedra suggest that additional biochemical responses to the pigment and P-I curve strategies that are most often discussed may be important when phytoplankton experience changes in the photic environment that are analagous in frequency to those encountered in situ. In 
P. mariae-lebouriae changes both in cellular carbon and pigment content occurred, but the time-courses for changes in these parameters differed. These changes were not linked to maintaining cell division, even though the magnitude of changes in pigmentation and photosynthesis that accompanied the shift of $P$. mariaelebouriae to low light was comparable to the magnitude reported for species that did continue dividing by photoadapting.

It appears that photoadaptation schemes based on results with cultures grown for weeks to months on a constant light intensity (cf. Prézelin and Sweeney, 1978, 1979; Prézelin, 1981; in press) may be incomplete, and that distinct strategies appropriate to particular time-frames of photic perturbation probably occur in the phytoplankton. The additional biochemical responses involved in photoadaptive strategies are probably associated with different frequencies of exposure to light shifts, as well as with the duration of exposure to a particular light regime. Sorting the cause and effect for these responses will obviously require much further study.

\section{Summary of photoadaptive responses in Prorocentrum mariae-lebouriae}

The photoadaptive responses that accompany changes in the photic environment supplied to Prorocentrum mariae-lebouriae are summarized in Table

Table 5. Directional changes in measures of cellular composition, growth, and photosynthesis elicited by changes in light availability

\begin{tabular}{|c|c|c|}
\hline \multicolumn{3}{|c|}{$\mathrm{A}($ High $) \longrightarrow \mathrm{B}($ Low $) \longrightarrow \mathrm{C}$ (Intermediate $)$} \\
\hline \multicolumn{3}{|l|}{ Parameter } \\
\hline Chl a & 1 & $\downarrow$ \\
\hline Chl $C$ & $\uparrow$ & j \\
\hline Peridinin & $\uparrow$ & $\downarrow$ \\
\hline Chl a : Chl $c$ (molar) & $\uparrow$ & $\downarrow$ \\
\hline peridinin : Chl a (molar) & $\downarrow$ & $\downarrow$ \\
\hline$\alpha$ cell $^{-1}$ & $\downarrow$ & $\downarrow$ \\
\hline$P_{\max }$ cell ${ }^{-1}$ & $\uparrow$ & $\downarrow$ \\
\hline$\alpha \mathrm{Chl}^{-1}$ & $\downarrow$ & $\downarrow$ \\
\hline$P_{\max } \mathrm{Chl}^{-1}$ & $\downarrow$ & $\downarrow$ \\
\hline$I_{s}$ & $=$ & $=$ \\
\hline$\mu_{\text {cell }}$ & $\downarrow$ & $\uparrow$ \\
\hline$\mu_{\mathrm{C}}$ & $\uparrow$ & $\downarrow$ \\
\hline $\int \mathrm{P}_{\mathrm{i}}-\int \mathrm{R}_{1}$ & $=$ & $\downarrow$ \\
\hline C & $\downarrow$ & $\downarrow$ \\
\hline $\mathrm{N}$ & $\downarrow$ & $\downarrow$ \\
\hline $\mathrm{C}: \mathrm{N}$ & $\uparrow$ & $\downarrow$ \\
\hline $\mathrm{C}: \mathrm{Chl} a$ & $\downarrow$ & $\downarrow$ \\
\hline
\end{tabular}

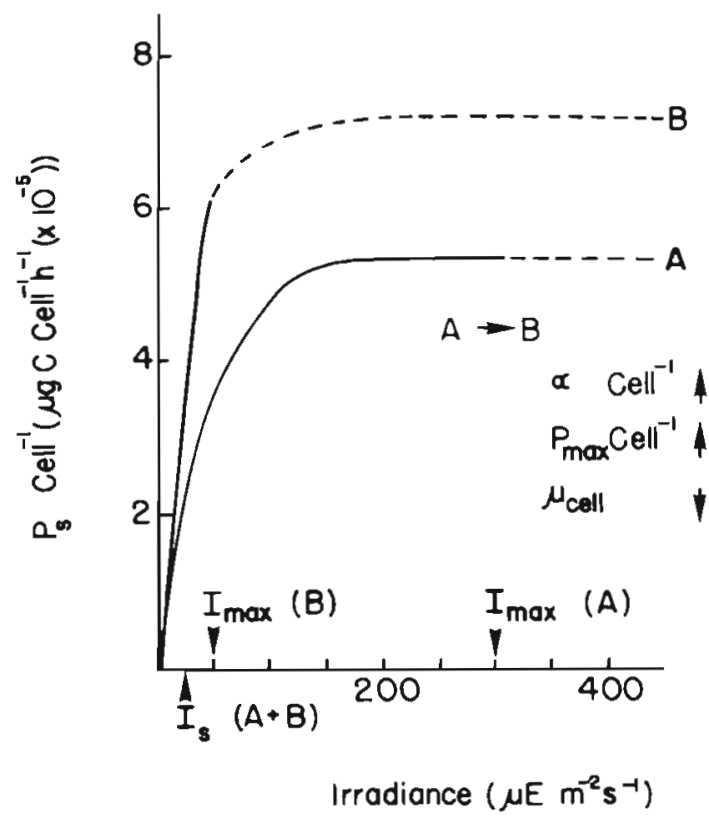

Fig. 9. Prorocentrum mariae-lebouriae. Summary of P-I curve changes accompanying the light shift from Cycle A to Cycle $B$. Curves represent daily mean $P$ per cell versus I plots for cells in each photic regime. Maximum irradiance experienced in each regime $\left(=I_{\max }\right)$ is depicted; dotted portions of P-I curves are portions outside the range of irradiances provided to cultures on light Cycles $A$ and $B$, respectively. Directions of $\alpha$ cell $^{-1}, \mathrm{P}_{\text {rnax }}$ cell ${ }^{-1}$, and $\mu_{\text {cell }}$ changes following the light shift are presented

5. Directional changes in measures of photosynthesis, cellular composition, and growth indicate that $P$. mariae-lebouriae photoadapts to a reduction in light availability, but that the responses are not sufficient to enable cells to continue dividing. Photosynthetic performance is enhanced following a shift from high to low light as the result of increased efficiency of light harvesting and carbon assimilation. Fig. 9 presents the daily average of $\mathrm{P}$ per cell vs. I curves for high and low light and summarizes the strategy $P$. mariae-lebouriae uses to cope with the light shift.

In summary, the photoadaptive strategy of Prorocentrum mariae-lebouriae is similar to strategies in other phytoplankton, and involves the rapid synthesis of pigments and associated proteins. Unlike other species, however, this shift in anabolism enables $P$. mariae-lebouriae to enhance net photosynthetic performance, but is insufficient to support a constant growth rate. Several elements of the strategy $P$. mariae-lebouriae uses to deal with reduced light availability do not appear to follow the schemes described for other phytoplankton species (reviewed by Prézelin and Sweeney, 1979; Falkowski, 1980; Prézelin, in press). P. mariae-lebouriae appears to combine several photoadaptive responses that previously 
have only been identified in separate species or under distinct experimental conditions. The main elements of the strategy include a leftward shift in P per cell vs. I curves associated with an increase in $a$ cell $^{-1}$, approximately equimolar increases in pigments, a reduction in cellular carbon content, and a cessation of cell division. Some of the pigment and P-I curve responses suggest a change in the 'number' of photosynthetic units (PSU's) per cell, but conflicting data indicate the 'size' of PSU's may change. Experimental conditions that were designed to mimic diel changes in sunlight intensity may have produced different adaptations than were described in previous studies with other dinoflagellate species, or $P$. mariae-lebouriae may possess a unique strategy that combines several biochemical responses.

The results of this study are probably applicable only to the time-frame of light adaptation encompassed in the experimental design. Photoadaptive strategies appear to have a great deal of temporal specificity that may be controlled by the frequency of changes in light intensity that phytoplankton experience. Descriptions of light adaptation strategies involving changes in cellular carbon content as distinguished from changes in pigment levels and photosynthetic parameters, for example, appear to be highly dependent on the frequency of changes in the photic regime (compare Prézelin and Sweeney, 1978, and Rivkin et al., 1982a). One aspect of this specificity in photoadaptive responses that we have attempted to address in this paper concerns a comparison of diel oscillations in light harvesting associated with photosynthetic periodicity to changes of a similar magnitude that accompany a shift in light availability. This separation of photosynthetic characteristics associated with rhythmicity from those truly representing photoadaptive changes is an important step in recognizing different time-scales of physiological responses. Beyond this effort, continuing work on rates of photoadaptation in Prorocentrum mariae-lebouriae will address the larger question of temporal specificity of photoadaptive responses in a subsequent manuscript that focuses on responses unique to different time-scales of photic perturbation.

Acknowledgements. We thank L. Brice, Dr. D. Coats, D. DelSignore, K. Henderson, M. Mallonee, E. Schiemer, and R. Whaley of CBI for assistance in various aspects of this research, Dr T. Platt of the Bedford Institute for providing computer software for P-I curve analyses, and Dr T Fisher of the University of Maryland for the carbon analyses. A portion of this research was supported by NSF Grant OCE 78-04981 to MAT. Chesapeake Bay Institute Contribution No. 280.

\section{LITERATURE CITED}

Beardall, J., Morris, I. (1976). The concept of light intensity adaptation in marine phytoplankton: some experiments with Phaeodactylum tricornutum. Mar. Biol. 37: 377-387

Boardman, N. K. (1977). Comparative photosynthesis of sun and shade plants. A. Rev. Pl. Physiol. 28: 355-377

Boczar, B. B., Prézelin, B. B., Markwell, J., Thornber, J. P. (1980). A chlorophyll $c$ - containing pigment - protein complex from the marine dinoflagellate, Glenodinium $\mathrm{sp}$ FEBS Lett. 120: 243-247

Brown, T. E., Richardson, F. L. (1968). The effect of growth environment on the physiology of algae: light intensity. J. Phycol. 4: 38-54

Dubinsky, Z., Falkowski, P. G. (1982). Effects of light intensity and duration of exposure on subsequent dark respiration rates in marine phytoplankton (Abstr.). Mtg. Am. Soc. Limnol. Oceanogr., San Francisco, 7-11 Dec. 1982, p. 961

Falkowski, P. G. (1980). Light-shade adaptation in marine phytoplankton. In: Falkowski, P. G. (ed.) Primary productivity in the sea. Plenum Press, New York, p. 99-119

Falkowski, P. G., Owens, T G. (1980). Light-shade adaptation. Two strategies in marine phytoplankton. Pl. Physiol. 66: 592-595

Fleischhacker, P., Senger, H. (1978). Adaptation of the photosynthetic apparatus of Scenedesmus obliquus. II. Differences in photochemical reactions, the photosynthetic electron transport and photosynthetic units. Physiol. Pl. 43: 43-51

Glibert, P. M., Goldman, J. C. (1981). Comparative winter and summer rates of phytoplankton photosynthesis in a north temperate coastal water (Abstr.). Mtg. Am. Soc. Limnol. Oceanogr., San Francisco, 7-11 Dec. 1982, p. 961

Guillard, R. R. L., Ryther, J. H. (1962). Studies of marine planktonic diatoms. I. Cyclotella nana Hustedt and Detonula confervacea (Cleve.) Gran. Can. J. Microbiol. 8: 229-239

Harding, L. W., Jr., Meeson, B. W., Prézelin, B. B., Sweeney, B. M. (1981a). Diel periodicity of photosynthesis in marine phytoplankton. Mar. Biol. 61: 95-105

Harding, L. W., Jr., Prézelin, B. B., Sweeney, B. M., Cox, J. L. (1981b). Diel oscillations in the photosynthesis-irradiance relationship of a planktonic marine diatom. J. Phycol. 17: 389-394

Harding, L. W., Jr., Prézelin, B. B., Sweeney, B. M., Cox, J. L. (1982a). Diel oscillations of the photosynthesis-irradiance (P-I) relationship in natural assemblages of phytoplankton. Mar. Biol. 67: 167-178

Harding, L. W., Jr., Prézelin, B. B., Sweeney, B. M., Cox, J. L. (1982b). Primary production as influenced by diel periodicity of phytoplankton photosynthesis. Mar. Biol. 67: $179-186$

Hellebust, J. A., Terborgh, J. (1967). Effects of environmental conditions on the rate of photosynthesis and some photosynthetic enzymes in Dunaliella tertiolecta Butcher Limnol. Oceanogr. 12: 559-567

Jeffrey, S. W. (1968). Quantitative thin-layer chromatography of chlorophylls and carotenoids from marine algae. Biochim. biophys. Acta 162: 265-270

Jeffrey, S. W. (1974). New spectrophotometric equations for determining chlorophylls $\mathrm{a}, \mathrm{b}, \mathrm{c}_{1}$, and $\mathrm{c}_{2}$ in phytoplankton, and higher plants. Rep. mar Biochem. Unit C.S.I.R.O. 1974: 6-8

MacCaull, W. A., Platt, T. (1977). Diel variations in the photosynthetic parameters of coastal marine phytoplankton. Limnol. Oceanogr. 22: 723-731

Malone, T. (1982). Phytoplankton photosynthesis and carbon- 
specific growth: light-saturated rates in a nutrient-rich environment. Limnol. Oceanogr. 27: 226-235

Mandelli, E. F. (1972). The effect of growth illumination on the pigmentation of a marine dinoflagellate. J. Phycol. 8: $367-369$

Marra, J. (1978). Effect of short-term variations in light intensity on photosynthesis of a marine phytoplankter: a laboratory simulation study. Mar. Biol. 46: 191-202

Marra, J. (1980). Time-course of light intensity adaptation in a marine diatom. Mar. Biol. Lett. 1: 175-183

Marra, J., Heinemann, K. (1982). Photosynthesis responses by phytoplankton to sunlight variability. Limnol. Oceanogr. 27: 1141-1153

Meeson, B. W. (1981). Comparative physiology of a typical red tide dinoflagellate, Gonyaulax polyedra, with a cosmopolitan species, Ceratium furca. Ph. D. thesis, University of California, Santa Barbara

Perry, M. J., Talbot, M. C., Alberte, R. S. (1981). Photoadaption in marine phytoplankton: response of the photosynthetic unit. Mar. Biol. 62: 91-101

Platt, T., Gallegos, C. L., Harrison, W. G. (1980). Photoinhibition of photosynthesis in natural assemblages of marine phytoplankton. J. mar. Res. 38: 687-701

Prézelin, B. B. (1976). The role of peridinin - chlorophyll a proteins in the photosynthetic light adaptation of the marine dinoflagellate Glenodinium sp. Planta 130: 225-233

Prézelin, B. B. (1981). Light reactions in photosynthesis. In: Platt, $T$ (ed.) Physiological bases of phytoplankton ecology. Can. Bull. Fish. Aquat. Sci. 210: 1-43

Prézelin, B. B. (in press). Photosynthetic physiology of dinoflagellates. In: Taylor, M. (ed.) The dinoflagellates. Blackwell, London

Prézelin, B. B., Alberte, R. S. (1978). Photosynthetic characteristics and organization of chlorophyll in marine dinoflagellates. Proc. natn. Acad. Sci. U.S.A. 75: 1801-1804

Prézelin, B. B., Ley, A. C. (1980). Photosynthesis and chlorophyll a fluorescence rhythms of marine phytoplankton. Mar. Biol. 55: 295-307

Prézelin, B. B., Matlick, H. A. (1980). Time-course of photoadaptation in the photosynthesis-irradiance relationship of a dinoflagellate exhibiting photosynthetic periodicity. Mar. Biol. 58: 85-96

Prézelin, B. B., Meeson, B. W., Sweeney, B. M. (1977). Characterization of photosynthetic rhythms in marine dinoflagellates. I. Pigmentation, photosynthetic capacity and respiration. Pl. Physiol, 60: 384-387

Prézelin, B. B., Sweeney, B. M. (1977). Characterization of photosynthetic Thythms in marine dinoflagellates. II. Photosynthesis-irradiance curves and in vivo chlorophyll fluorescence. Pl. Physiol. 60: 388-392

Prézelin, B. B., Sweeney, B. M. (1978). Photoadaptation of photosynthesis in Gonyaulax polyedra. Mar. Biol. 48: 27-35

Prézelin, B. B., Sweeney, B. M. (1979). Photoadaptation of photosynthesis in two bloom-forming dinoflagellates. In: Taylor, D. L., Seliger, H. H. (ed.) Toxic dinoflagellate blooms. Elsevier/North-Holland, New York, p. 101-106

Rivkin, R. B., Seliger, H. H. Swift, E., Biggley, W. H. (1982b). Light-shade adaptation by the oceanic dinoflagellates Pyrocystis noctiluca and $P$. fusiformis. Mar. Biol. 68: 181-191

Rivkin, R. B., Voytek, M. A., Seliger, H. H. (1982a). Phytoplankton division rates in light-limited environments: two adaptations. Science, N. Y. 215: 1123-1125

Senger, H., Fleischhacker, P. (1978). Adaptation of the photosynthetic apparatus of Scenedesmus obliquus to strong and weak light conditions. I. Difference in pigments, photosynthetic capacity, quantum yield and dark reactions. Physiologia Plant. 43: 35-42

Sournia, A. (1974). Circadian periodicities in natural populations of marine phytoplankton. Adv. mar. Biol. 12: 325-389

Steeman Nielsen, E. (1952). The use of radioactive carbon $\left(\mathrm{C}^{14}\right)$ for measuring organic production in the sea. J. Cons. int. Explor. Mer 18: 117-140

Steeman Nielsen, E. Park, T. S. (1964). On the time-course in adapting to low light intensities in marine phytoplankton. J. Cons. int. Explor. Mer 29: 19-29

Strickland, J. D. H., Parsons, T. R. (1968). A practical handbook of seawater analysis. Bull. Fish. Res. Bd Can. 167: $1-311$

Sweeney, B. M., Hastings, J. W. (1957). Characteristics of the diumal rhythm of luminescence in Gonyaulax polyedra. J. cell. comp. Physiol. 49: 115-128

Tyler, M. A., Seliger, H. H. (1978). Annual subsurface transport of a red tide dinoflagellate to its bloom area: water circulation patterns and organism distributions in the Chesapeake Bay. Limnol. Oceanogr. 23: 227-246

Tyler, M. A., Seliger, H. H. (1981). Selection for a red tide organism: physiological responses to the physical environment. Limnol. Oceanogr. 26: 310-324

Yentsch, C. S., Lee, R. W. (1966). A study of photosynthetic light reactions and a new interpretation of sun and shade phytoplankton. J. mar. Res. 24: 319-337 